\title{
A Professional Teacher as 'Bartleby the Scrivener'? Rather not! Occupational Burnout in the Teaching Profession Helena Zbudilová
}

\author{
'I would prefer not to.' \\ H. Melville, Bartleby the Scrivener (1856)
}

The opening story from Wall Street, in connection with the current topic of Caritas et Veritas, will lead us to a deeper reflection of the teacher's profession and the burnout syndrome thread. We will deal with the contemporary perception of teaching as a convergence of employment, occupation, mission, and calling: the teacher as a labourer, a craftsman or an artist, and a reflective professional, researcher, and expert at the same time. We will also reflect on the current status of the teaching profession in the 21st century and the insufficiently explored burnout syndrome phenomenon in the life of teachers. We will offer three case studies demonstrating the severity of this psychosomatic disorder, also called the psychological 'heart attack' of the postmodern individual by Byung-Chui Han, a contemporary philosopher publishing in the German language. ${ }^{1}$

\section{Introduction}

The words of the introductory quotation above (expressing the passive resistance of an individual) refer to the sad human fate of the writer Bartleby, who was introduced by the American writer Henry Melville in the mid-19th century. This is the tragic life story of an unusual protagonist (an anti-hero, a lower-ranking official), who is incredibly work-efficient and reliable, and (at the same time) mysterious, without friends, living in complete solitude, harmless, uncommunicable, almost silent, always present, deserted in a space by the bare office wall. His story offers a number of interpretations: 'He worked from morning to evening, copying texts in daylight or with the light of a candle. I would have enjoyed the fervor if his work was somewhat cheerful, but he wrote quietly, mechanically, with a pale, motionless face.' ${ }^{2}$ One day, there is a reversal of his behaviour. He is asked to do another job, but he refuses. Gradually he refuses everything. He ends up in prison, where he dies purposefully in his solitude by the high, cold wall. We see how the life power leaves his tired body. It is visible in his open grey eyes 'with faded tranquillity.' There is much

Cf. Byung-Chui HAN, Vyhořelá společnost, Praha: Rybka Publishers, 2016, p. 17.

2 Herman MELVILLE, Písař Bartleby. Př́běh $z$ Wall Streetu. The original book Bartleby the Scrivener (Stories of the American Experience) was translated by Radoslav Nenadál. He also added an epilogue. Praha: Odeon, 1990, p. 27. 
interpretation of the story. The interpreter R. Nenadal, for example, mentions the issue of human communication problems, the sense of alienation in society, the tragedy of non-engagement or aversion to engagement, the tragedy of passivity, the reluctance to conform and adopt models of society, the negation of society, and the choice of self-destruction. ${ }^{4}$ In the story of the aboulic official, we are attracted by the overall feeling of vanity that his soul suffered from. A sense of vanity rising from a professional life, a feeling of vanity from a personal life. On the professional level, he was probably completely demotivated due to work with the undelivered 'dead' letters that he was sorting for burning; on a personal level, he was completely isolated, stuck in his present life. Although the story was written more than a century and a half ago, it anticipates many of today's $21^{\text {st }}$ century people who have the burnout syndrome problem. Looking more closely at the character of Bartleby, we see that he has typical symptoms of burnout - these are feelings of physical, emotional, and psychological exhaustion. He is visibly tired, emotionally extinct, with a sick image, as if in distress, hopelessness and depression, lifeless, trapped, depersonalised, bitter, feeling vanity of his own existence, zero self-confidence, and gradually reducing his working performance to almost zero.

Bartleby does not communicate with anyone in his environment, he is unable to perceive himself, to have a relation with his own internal core. He loses the sense of everything. M. D. Rush and D. Heczko use the biblical character of the prophet Elijah to interpret burnout syndrome and refer to the disease as 'Elijah Syndrome.' The Biblical text states: 'while he himself went a day's journey into the wilderness. He came to a broom bush, sat down under it and prayed that he might die. "I have had enough, Lord," he said. "Take my life; I am no better than my ancestors."'(1 Kings 19:4) God puts another mission before Elijah, confirms the importance and value of his life, and frees him from anxiety. Elijah managed to overcome his traumas and purify his trust in God. ${ }^{6}$ Is your life a ruin? You have a chance - that is the biblical answer. It is necessary to step out of the role of the victim.

As evidenced by the case of the writer Bartleby and the Prophet Elijah, the originally burning fire (symbolised psychologically by high motivation, interest, activity, and commitment) changes into the loss of fire and burnout. There is no material available to feed the fire. ${ }^{7}$ We see it in the literary parallel of Bartleby. However, we see the opposite in the case of the prophet Elijah. A. Grün brings (in the book called Burnout: How to make your own energy flow again) the healing biblical picture of the inner fire as one of the possible therapies:

Sit down, close your eyes and go to the bottom of your soul. There you feel the burnout. There is just the ash. But go deeper. Imagine that there are still glowing coals under this ash. Imagine that you are heating them up, then they start to glow again and eventually they start to burn. Under the ash that drifts in us, there is a glow. I call it the heat of the Holy Spirit. It is in each of us, whether we want or do not want to. ${ }^{8}$

In what sense has the world of the third millennium (giving birth to the descendants of Bartleby) changed? The current postmodern situation in society and growing globalisation emphasise

Cf. Radoslav NENADÁL, Epilogue. Ibid., pp. 107-109.

Cf. Daniel HECZKO, Už nemohu dál: o syndromu vyhoření, Třinec: Biblos, 2000, p. 14. Myron D. RUSH, Syndrom vyhoření, Praha: Návrat domů, 2003, p. 48.

6 Cf. Jana ŘEZBOVÁ, Syndrom vyhoření u kněží. Diplomová práce. Praha: TF JU, 2007, p. 57.

7 Cf. Zuzana PAPÍKOVÁ, Syndrom vyhoření: Rizikové faktory jeho vzniku. Diplomová práce. Praha: FF UK, 2013, p. 6.

8 Cf. Anselm GRÜN, Vyhoření: Jak rozproudit vlastní energii, Praha: Portál, 2014, p. 115. 
the individual performance. The imperative of performance has become a new commandment of today's working society. In addition to the cult of performance, other demands are being promoted like the cult of profit, career, the hybrid of work and career advancement, prestige, and entertainment. The pace of life is rising. Man is overwhelmed by work and fun, running away from him or herself. The load of any kind and stress become natural parts of life. Being was turned into action - a 'vicious circle of labour, use and consumption'. The only persistent value in the world of postmodern relativism remains the market. The society overwhelmed by information strives to obtain the status of a society filled with knowledge. No wonder that burnout syndrome is spreading its network in the form of the 21 st century's dominant disease. It is a silent enemy, accompanying its victims at first as an invisible shadow. Later, it subsequently withdraws all the energy sources of man and leads him or her to the complete extinction of his or her life's fire. The victim is then thrown into the claws of social death.

\section{Burnout Syndrome and Teachers}

In today's performance society, individuals are seen primarily as subjects of performance. Although we have almost limitless possibilities for realisation, we paradoxically lose our freedom and sovereignty, and we really can arrive at the position of first and foremost working man (animal labours). Philosopher Han defines this type of man of the new millennium, who is overwhelmed by impulses (living in the tow of so-called neural violence), is an exhausted egoist, hyperactive, hyper-attentive, hyper-neurotic, and tired. He exploits himself as a predator and prey at the same time, gives the energy to be what he or she is and weakens his or her social ties. ${ }^{9}$ From the overflow of stimuli, although positive, there is a small step taken towards the development of burnout syndrome. Burnout syndrome is a professional term that appeared in psychology and psychotherapy in the 1970s. It was first used by Hendrich Freudenberger. ${ }^{10}$ It characterises psychosomatic ${ }^{11}$ states of exhaustion, which are mainly related to professions where the duty is to give service to other people. The assisting professions are diverse (doctors, nurses, social workers, educators, psychologists...) and are perceived as a risky profession from the point of view of interpersonal relations and psychological stress. The consequences of ignoring the syndrome can be crucial not only for individuals but also for society as a whole. It is a complicated multifactorial phenomenon which, in our opinion, is not fully perceived and reflected upon in the present society. It brings negative phenomena such as employee exhaustion, health and psychological problems, increased sickness, departure from the profession, and early retirement. The syndrome is so far understood to be an individual's affair, his or her personal failure or exhaustion. The systematic level is overlooked. The fact that the Czech Ministry of Labour and Social Affairs is currently considering the inclusion of burnout syndrome among occupational diseases may contribute to the improvement of the current situation. The French Ministry of Labour and Social Affairs has recently changed their law. The burnout syndrome diagnosis involved 3.2 million French people in 2016 who (according to medical statistics) were on the verge of burning out. ${ }^{12}$

9 Cf. HAN, Vyhořelá..., pp. 12-16, 27.

10 Cf. Jaro KŘIVOHLAVŶ, Hořet, ale nevyhořet, Kostelní Vydří: Karmelitánské nakladatelství, 2012, p. 58.

11 Marie TĚTHALOVÁ, To, jak žijeme, máme ve svých rukou. Rozhovor s MUDr. Olgou Kunertovou, Informatorium 6/2017, p. 7.

12 Cf. ( ) Jana ŠAFǍ̌íKOVÁ, Budou mít Francouzi právo se po práci „odpojit“?, Mladá Fronta Dnes, 18. 2. 2016 (on-line), available at: http://www.pressreader.com/czech-republic/mf-dnes/20160218/, update $18^{\text {th }}$ February 2016, cited 15 ${ }^{\text {th }}$ June 2017; (C) Markéta MIKEŠOVÁ, Francouzi dostali právo být offline. Novela zákoníku práce umožňuje ignorovat emaily a vypnout mobil, available at: https://www.zive.cz/bleskovky/francouzi-dostali-pravo-byt-offline-novela-zakoniku-prace-umoznuje-ignorovat-emaily-a-vypnoutmobil/sc-4-a-185455/default.aspx, cited $2^{\text {nd }}$ January 2017. 
Burnout syndrome is not yet classified as a disease. According to the current International Classification of Diseases (MKN 10), it is not a primary diagnosis. It is classified as an additional diagnosis that can be assigned to some of the primary diagnoses (e.g., depression). However, the symptoms of burnout syndrome can be found in $20-30 \%$ of people who come into contact with other people at work. ${ }^{13}$

In the Czech Republic, there is a number of professional works, popular educational titles, and bachelor and diploma theses that show this topic to be a highly up-to-date one. If we look at the EBSCO database, there are 27,127 studies on burnout syndrome from the 1990s to the present. The Czech database of final written theses contains about 900 links to burnout syndrome. Topics of bachelor and diploma theses ${ }^{14}$ deal (most frequently) with the presence of burnout syndrome at primary and secondary schools, but we also find a number of works dealing with the subject in pre-school education and, rarely, also in university settings. In general, studies giving the definition of burnout syndrome (stress and depression) prevail and these identify the rate of burnout in a given occupational category at a particular type of school or within one school. There are works devoted to the description of burnout factors (explanatory, facilitative, and protective ones).

Burnout syndrome is included in the Pedagogical Dictionary, where it is understood as the ultimate consequence of long-term psychological pressure and time and physical burdens in teaching. It is professional burnout, the final stage. J. Prucha states that

\begin{abstract}
Abroad and also in the Czech Republic or Slovakia, there are relatively high numbers diagnosed when talking about the degree of burnout of teachers. The emotional area seems to be the riskiest. Nevertheless, it appears that psychological burnout is generally not higher in the area of teaching than in other professions (which are focused on communication and relationship with clients, i.e., demanding assisting professions. ${ }^{15}$
\end{abstract}

The first professional group which focused on research in the Czech environment in the form of a nationwide study on depression were doctors. Two years ago, the team of the First Faculty of Medicine of Charles University carried out research dealing with the medical profession's burden of burnout syndrome. It has been proven that roughly a third of doctors have the symptoms of burnout syndrome. R. Ptáček, an associate professor of the First Faculty of Medicine, points to foreign studies revealing that this number is much higher in several other countries, including the United States. ${ }^{16}$ The investigation has brought interesting findings that (for medical doctors) the

13 Cf. Zuzana DAŇKOVÁ, Hořet a nevyhořet, Psychologie Dnes, únor 2017, pp. 56-57.

14 For example Kateřina SLANINOVÁ, Syndrom vyhoření u učitelů (diploma theses), Ostava: PF OU, 2016; Irena BOBYLEVA, Syndrom vyhoření u učitelů středních škol (bachelor theses), Brno: MENDELU, 2017; Vlastimil KARAFIÁT, Syndrom vyhoření u učitelů středni odborné školy (bachelor theses), Praha: ČVUT, 2017; Veronika FILIPOVÁ, Celoživotní vzdělávání jako prevence syndromu vyhoření (diploma theses), Brno: FF MU, 2017; Michaela KLIMEŠOVÁ, Syndrom vyhoření u učitelù středních škol (diploma theses), České Budějovice: PF JU, 2016; Dominika BAKLÍKOVÁ, Syndrom vyhoření u středoškolských učitelů (bachelor theses), Zlín: FHS UTB, 2015; Jaromír BÍLYY, Syndrom vyhoření u učitelu (diploma theses), Ostava: PF OU, 2015; Sandra SVOBODOVÁ, Syndrom vyhoření u učitelů (diploma theses), Plzeň: PF ZČU, 2015; Kateřina ŠPRINGLOVÁ, Syndrom vyhoření u učitelů mateřských škol (bachelor theses), Olompouc: PF UP, 2014; Štěpánka HAVLÍČKOVÁ, Syndrom vyhoření pedagogů (bachelor theses), Praha: UJAK, 2014; Petr KALKANT, Syndrom vyhoření u učitelů na středních školách (bachelor theses), Ústí nad Labem: PF UJEP, 2014; Jana MIKULECKÁ, Syndrom vyhoření u učitelì (bachelor theses), Ústí nad Labem: PF UJEP, 2014; Jan BOHÁČ, Syndrom vyhoření a riziko jeho vzniku u učitelů na 2. stupni ZŠ (bachelor theses), Pardubice: FF UPa, 2013; Kamila MACHOVCOVÁ, Syndrom vyhoření u učitelù 2. stupně ZŠ (diploma theses), České Budějovice: PF JU, 2014; Ilona NESVADBOVÁ, Syndrom vyhoření učitele (bachelor theses), Olomouc: FF UP, 2013; Jolana ZACHOVÁ, Syndrom vyhoření z pohledu učitelů v praxi a možnosti jeho předcházení (diploma theses), Brno: PF MU, 2010; Lenka STIBŮRKOVÁ, Syndrom vyhoření v učitelské profesi (diploma theses), Brno: PF MU, 2007.

15 Jan PRŮCHA (ed.), Pedagogická encyklopedie, Praha: Portál, 2009, p. 406.

16 Cf. Radmil ŠVANCAR, Má vaše práce smysl?, Učitelské noviny 1/2017, p. 20. 
risk of developing burnout syndrome is highest in the first five or six years when they enter the profession and (at the same time) are preparing themselves for their postgraduate certification. The risk declines over the years. Teachers are supposed to suffer from burnout syndrome primarily at the teacher-expert stage (at pre-retirement age), but even early-stage teachers can expect a similar risk. They come to schools with élan, optimism and enthusiasm, but they often come into conflict with reality. This is confirmed by the research conducted by W. Hagemann, who dealt with the occurrence of burnout syndrome in Germany. He confirmed that those teachers who have more than twenty years of practice are the most endangered, but even beginners can become ill. ${ }^{17}$ The most common stressors in the German education system were the atmosphere in the teaching team, the competence of managers, the lack of resting time, the value of breaks in teaching, the loneliness, the lack of supervision, class size, the behaviour of problematic students, the number of hours, coordination of work and private duties, and obligations outside the teaching area. Teachers felt overworked, as well as feeling as if they could not develop their abilities, and were left without help..$^{18}$ The conflict with reality is explained by A. Staněk, the author of qualitative research about the professional identity of a teacher of social sciences:

As a result of the practice, there is first a shock associated with entering the reality of the teaching profession. This initial shock and the subsequent two to three-year stage of a teacher beginner brings a duel of ideals (preconcepts) and reality. It is led both in the teacher's soul and on the external battlefields - in classrooms, teachers' common room and with the parents. The decisive factors in this professional phase are endurance, tenacity and commitment to the teaching profession. These should be linked to openness to external stimuli (the ability to be tuned to the right frequency) and thus to readiness for professional metamorphoses. ${ }^{19}$

The second professional group currently undergoing national research are teachers. At the end of 2016, a study called 'The Burning Syndrome of Primary School Teachers' was launched. Data from 1000 to 1500 teachers were collected through an on-line questionnaire survey by the end of February this year. This research is managed by the Psychiatric Clinic of the First Medical Faculty of Charles University together with the Department of Psychology of Charles University. The research will capture not only the professional characteristics of the teacher (how long, what and where he or she teaches) but also other personal data about lifestyle, eating habits, smoking, drinking alcohol, physical movement, stress management, etc. The study seeks to determine whether and to what extent burnout syndrome is developed there and also the burden of professional tiredness or depression..$^{20}$ The research will certainly provide valuable insights that can be implemented in the preventive programs dealing with burnout syndrome. The syndrome develops due to several basic phases and does not necessarily have to reach the final stage. There may also be a partial burnout. Amongst teachers, there is not a habit of the supervision practice which would offer enough space for reflection of their own work, work practices, and relationships in the workplace, and which would give the opportunity to stop, think, and talk with colleagues, communicate new ideas, and become inspired. The use of individual, group or team supervision (unlike in the

17 Cf. Wolfgang HagemanN, Syndrom vyhoření u učitelu․ Přičiny, pomoc, terapie, Ústí nad Labem: Univerzita Jana Evangelisty Purkyně, 2012, p. 10.

18 Ibid., p. 11.

19 Antonín STANĚK, Kvalitativní výzkum profesní identity učitele výchovy k občanství, Praha: Epocha, 2010, cover.

20 For the questions of the study, see www.ucitelskevyhoreni.cz. 
social work environment) is not yet common in the school environment. ${ }^{21}$ Various interventions and ways to counteract professional fatigue must also go hand in hand with a change in lifestyle, appropriate leisure time, and positive interpersonal relationships.

\section{A Teacher of the 21st Century - Professional, Individual, Worker (Professional Convergence)}

One key to the 21st century is the concept of the so-called learning society, the concept of learning throughout life. Education in the 21st Century (according to the document Learning: The treasure within: A report to UNESCO of the International Commission on Education for the twenty-first century.) is supposed to be based on four pillars: to know, to do, to be, and to live together. According to the OECD document, teachers are key players in the society of knowledge in all strategic processes aimed at supporting the development of society and the economy. ${ }^{22}$ In all models of quality school, the teacher's figure plays a key role. The quality of teachers is a key factor that fundamentally influences the quality of education. Teachers' quality characteristics include knowledge, pedagogical and didactic skills, attitudes, values, and personality traits. ${ }^{23} \mathrm{~A}$ key European trend is to support the professionalisation of teaching. The key features of the profession are the existence of professional/expert knowledge, awareness of public service, lifelong engagement, and a commitment to working with pupils. ${ }^{24}$ The teacher must be a professional. At the same time, however, he or she goes beyond his or her professionalism. ${ }^{25}$ According to Zdeněk Helus, the professionalism of teachers is based on their knowledge, skills and competencies. Sociologists often place teaching in the category of semi-professions. Among the reasons given for the defence of this classification are, for example, the following statements: the work is carried out in large hierarchical bureaucratic organisations which are subject to administrative (not professional) authority, there is a large number of job executors, etc. ${ }^{26}$

The term 'occupation' refers to the teacher's personality and its moral anchorage. Teaching as a profession or mission (in contrast to mere employment) accentuates the personality and its pedagogical virtues. It is based on the thesis that a teacher with his or her personal qualities (by who he or she is, how he or she acts, what he or she represents) influences most effectively his or her students on the way to their own personal development. The teacher is a model of critical, creative and engaging personality. The teacher and his or her personal life (reflected in his or her value orientation, the complexity of his or her personality, in the unity of words and deeds, in the spirit of the classic 'Exempla trahunt') plays a key role. The teacher's pedagogical virtues represent pedagogical love, wisdom, courage and credibility. ${ }^{27}$

S. Štech has developed three alternative models of the teacher as a metaphor of teaching - the model of 'worker', 'craftsman' and 'artist.' ${ }^{28}$ The 'worker' model is related to planning (e.g., the planning of target competencies), to the quantity of work tasks (e.g., administrative and auxiliary activities), and the quality control of the standard (i.e., control of curriculum, textbooks, didactics, assessment, etc.). For the 'craftsman' model, work performance is not standardised, but is directed

\footnotetext{
Cf. Marie TĚTHALOVÁ, To, jak žijeme..., p. 7.

Cf. Zdeněk HELUS - Noemi BRAVENÁ - Marta FRANCLOVÁ, Perspektivy učitelství, Praha: PF UK, 2012, p. 9.

3 Cf. Vladimíra SPILKOVÁ - Anna TOMKOVÁ a kol., Kvalita učitele a profesní standard, Praha: PF UK, 2010, p. 22.

Ibid., p. 37.

Cf. HELUS - BRAVENÁ - FRANCLOVÁ, Perspektivy učitelství, p. 124.

Cf. Stanislav ŠTECH, Profese učitele, p. 2.

Cf. HELUS - BRAVENÁ - FRANCLOVÁ, Perspektivy učitelství, pp. 41-42.

Cf. Stanislav ŠTECH, Profese učitele, pp. 4-5.
} 
to an individualised product. The work is performed in a relatively autonomous way and is not extensively controlled externally. In this case, experience based on practice is predominant. For the 'artist' model, the teacher's personality, sensitivity, and creativity are at the forefront.

The basis is the expression of the teacher's authentic experience as a person and also the expression of a free creative activity. If the first two models put emphasis on doing, the 'artist' model represents the authenticity of being. In pedagogical practice, each teacher combines the elements of these three models, and from this perspective, the teaching profession appears to be mixed (to be a hybrid), i.e., more susceptible to burnout syndrome. The teacher should also embody the way of going beyond for the pupil and motivate him or her to go this way. For education to turn around, transcendence is a new stimulus. It means abandoning self-centeredness and going beyond yourself towards a particular goal, subject, or object, and this can have not only an educational but also a therapeutic effect. ${ }^{29}$

The current position of the teaching profession in the era of postmodern education is complex, because the fulfilment of the teacher's professional existence is influenced by imbalanced views in society and by the teachers themselves, specifically the views on the teacher's professional identity. On one hand, teachers repeatedly complain about the lack of respect and appreciation, long-term underfinancing, struggling with constant changes (change of school law, career law, reform of regional education funding), increasing administration, educational problems with pupils and problems with parents; on the other hand, surveys show that teachers are among the respected professions that are repeatedly placed at the top of the social rankings of professions.

Contemporary forms of teaching can be perceived through three prisms - teaching as a job, teaching as a mission, and teaching as a profession. We cannot talk about a single dominant form. It is rather an unbalanced convergence of these concepts. The foundation is professionalisation (the professional basis of the field) which is intensively discussed mainly in connection with career law. Nowadays, it is necessary to emphasise the concept of teaching as a profession-mission (not a mere occupation), with a return to the archetypal concept of the teacher as a developed personality, which (according to Z. Helus) includes not only pedagogical love, but also pedagogical wisdom, pedagogical courage and pedagogical credibility. ${ }^{30}$ Opinions dealing with the defining of teaching as a profession are not uniform among experts. V. Spilková (who compared the current state of professionalisation of teaching in a number of developed countries with the situation in the Czech Republic) concluded that in our country teaching still persists at the level of semi-profession or, in many aspects, it leads to deprofessionalisation. She explains that the key features of a real profession are not fulfilled - there is no professional standard, ethical code, or professional chamber. The degree of internally accepted occupational autonomy and the professional responsibility of most teachers are also inadequate. Teachers have worked for many years under the conditions of the so-called limited professionalism model in the predominant concept of teaching as a job. They have been perceived as executors, implementers, curriculum consumers with minimal professional autonomy. Spilková also refers to the unpreparedness of a large number of teachers for the new job requirements (in particular) related to curricular reform:

Some authors (Helus, Straková, Spilková...) talk about the crisis of teaching, about teachers as a weak element of transformational changes, about their inability to cope with new demands, their unwillingness to leave stereotypes at work, unwillingness to learning new

29 Cf. HELUS - BRAVENÁ - FRANCLOVÁ, Perspektivy učitelství, p. 49.

30 Cf. ibid., pp. 41-42. 
things or to be engaged in the long-term process of their own transformation (along with the transformation of the school)..$^{31}$

We tend to develop the teacher's professional competence in the spirit of constructivist and personalistic models, where the teachers' professional models are reflected (specifically, a teacher as a reflecting professional, a teacher as a researcher, and a teacher as an expert). ${ }^{32}$ The teacher as a reflecting professional checks and evaluates his or her own pedagogical practice, and works on the formation of his or her professional self. The teacher as a researcher examines the concept of his or her own work via the research process, i.e., he or she develops professional values, knowledge and practice. The teacher as an expert is a professional model that combines the abilities of the previous two categories at a high level. ${ }^{33}$ Over time, it will be proven that the phenomenon of the career order will contribute to the development of a demanding teacher's profession as a fully-fledged expert profession in 21st century society.

Teaching (as a profession) is nowadays considered to be a burden, it is an unsecure job, and sometimes the profession is even attacked. ${ }^{34}$ Newer and newer demands are being placed on teachers, such as the integration of disadvantaged children (socially, psychologically, physically, etc.), the integration of pupils with specific educational needs and children from different cultures, prevention of bullying and socially pathological phenomena, introduction of new technologies, indiscipline, work with gifted and talented pupils. Teachers experience frequent changes in educational projects and school organisation, they are witnessing inconsistencies in the management of the ministry (for example, from 1993 to 2016, 16 ministers of education were appointed), they are experiencing a lack of activity from higher education authorities. Teachers are exposed (for different reasons and from different sides) to criticism. The family, the public, and society often project their own failures onto them. ${ }^{35}$ They are more vulnerable to cyberbullying. They often perceive their profession as undervalued. There is a lack of motivation for teacher's professional development, an unmet need for self-realisation often leading to frustration, and there are no career opportunities. There is no fully-fledged career law as an important element in the professionalisation of the teaching profession. Teaching is often associated with the emergence of conflicting, frustrating or stressful situations. The teacher is in contact with many people for most of the working time. He or she is constantly monitored and controlled. The profession is associated with an extensive time load and work overload. The teacher's job is found high up on the list of occupations threatened by burnout syndrome.

\section{Case Studies in the Family}

For the purposes of this study, a different procedure was chosen than had been used in already existing empirical studies. The major part of these studies mainly focuses on quantitative research searching for the presence of burnout syndrome among teachers at selected schools; in our case it is qualitative research which uses not only a qualitative but also a quantitative research tool. We therefore sought to identify the current state of burnout syndrome and its extent among three teachers from different grades and from the same family context (we focused on two generations). The family was

31 Vladimíra SPILKOVÁ, Př́stupy české vzdělávací politiky po roce 1989: Deprofesionalizace učitelství a učitelského vzdělávání?, Pedagogika 4/2016, pp. 370-371.

32 Cf. Jitka LORENZOVÁ, Kontexty vzdělávání v postmoderní situaci, Praha: FF Univerzity Karlovy v Praze, 2016, p. 278.

33 Ibid., pp. 278-280.

34 Cf. HELUS - BRAVENÁ - FRANCLOVÁ, Perspektivy učitelství, p. 5.

35 Ibid., p. 49. 
carefully selected in advance. A quantitative survey consisted of the assignment and evaluation of four standardised questionnaires aimed at determining the stress burden on the body, ${ }^{36}$ the intensity of emotional load, ${ }^{37}$ the risk of burnout syndrome, ${ }^{38}$ and the degree of psychological burnout. ${ }^{39} \mathrm{We}$ therefore sought to find out the current state of the body load and the degree of sensitivity to stress and burnout in the cases of three teachers from different types of educational institution. The questionnaire itself took the respondents (on average) one hour; the evaluation of the questionnaires was carried out according to the given criteria. The objective of the qualitative survey was to penetrate deeper into the issue, specifically into the interconnection of the stress burden and burnout syndrome with the individual 'professional and personal stories' of a selected sample of pedagogues. The various influence of internal and external risk factors (which leads to burnout syndrome) was expected to be obvious in the selected sample of participants. Qualitative research, conducted through a structured interview with open questions, took (on average) 30-40 minutes. It was supplemented by the continuous writing of notes in the recording sheet and by audio recording. This background was used to create three case studies.

The research sample was chosen purposefully; the process of targeting (of the sample group) was longer, for the intention was to gain a sample for a multi-generational research probe. A two-generation research sample was obtained, which included a mother (a teacher) and two daughters (teachers). In the case of a multigenerational survey, we were also exploring if any of the mother's experience with stress and burnout syndrome might be reflected in the professional behaviour of her daughters. It was found (in advance) that the members of the research sample maintain a positive relationship to the profession, enjoyed or still enjoy teaching, and have been recognised in their position.

There are three teachers from different levels - primary school (mother - teacher Anna), high school (daughter - teacher Teresa) and college (daughter - teacher Zuzana). They have different teaching experience ranging from 23 to 36 years. Each teacher first completed four written questionnaires, followed by a semi-structured interview with each of them separately.

For the sake of clarity, we have placed the results of the standardised questionnaires in the following tables:

Stress susceptibility questionnaire:

\begin{tabular}{|llll|}
\hline & Anna & Tereza & Zuzana \\
the effects of stress on & high & low & high \\
cognitive skills & $(12)$ & $(10)$ & $(22)$ \\
the effects of stress on & high & average & high \\
emotions & $(18)$ & $(14)$ & $(20)$ \\
the effects of stress on & high & high & high \\
the body & $(27)$ & $(21)$ & $(22)$ \\
The consequences of & average & low & average \\
stress in social life & $(14)$ & $(10)$ & $(15)$ \\
\hline
\end{tabular}

36 Cf. Václav HOLEČEK, Psychologie v učitelské praxi, Praha: Grada, 2014, pp. 192-193.

37 Cf. Thomas POSCHKAMP, Vyhoření. Rozpoznání, léčba, prevence, Praha: Albatros Media, 2014, pp. 51-52.

38 Cf. HOLEČEK, Psychologie..., pp. 194-195.

39 Ayala M. Pines and Elliot Aronson's psychological burnout questionnaire (BM) tracks three aspects of exhaustion: feelings of physical exhaustion, emotional and psychic exhaustion. The calculated value of BQ is the value of the person's mental burnout. Cf. Jaro KŘIVOHLAVÝ, Hořet..., pp. 49-52. 
The most pronounced susceptibility to stress was reported by Zuzana (a college teacher) in the cognitive field (she had the highest number of all three respondents), and on the body and emotional level as well; Anna (a primary school teacher) reported the highest perceived consequences of stress, especially in the physical field (she reached the highest value of all given areas) and then in the emotional area. The high level of consequences due to physical stress is also evident in the case of the high school teacher Tereza. It is obvious that the consequences of stress in the body are subjectively perceived by respondents more intensely than emotional consequences. A surprising fact is the high degree of stress in the cognitive area given by Zuzana, the college teacher.

Questionnaire regarding emotional load

\begin{tabular}{|llll|}
\hline & Anna & Tereza & Zuzana \\
$\begin{array}{l}\text { Emotional exhaus- } \\
\text { tion }\end{array}$ & high (3.7) & average (2.44) & high (4.1) \\
$\begin{array}{l}\text { depersonalisation / } \\
\text { cynicism } \\
\begin{array}{l}\text { performance reduc- } \\
\text { tion }\end{array}\end{array}$ & average (1.4) & low (0.2) & low (0.6) \\
\hline
\end{tabular}

The emotional load questionnaire responds to the individual features of respondents' personalities. The highest level of emotional exhaustion was given by Zuzana (the university teacher), a slightly lower level of the burden was also achieved by the primary school teacher. The most significant numbers of depersonalisation (cynicism) were given by Anna (the teacher from the primary school). All three respondents are experiencing a decrease in job performance (there are high numbers in results given by the primary and high school teacher).

Questionnaire detecting the risk of burnout syndrome

\begin{tabular}{|ll|}
\hline Anna & average (146 points) \\
Tereza & average (158 points) \\
Zuzana & average (154 points) \\
\hline
\end{tabular}

All of the teachers (in the questionnaire detecting the risk and the level of burnout syndrome) had average results with a maximum difference of 12 points.

Burnout Syndrome Questionnaire (BQ equals the threat value)

\begin{tabular}{|c|c|}
\hline Anna & $\begin{array}{l}\mathrm{BQ}=3.4 \text { to think about life and work, the style and meaningful- } \\
\text { ness of life }\end{array}$ \\
\hline Tereza & $\mathrm{BQ}=2.2$ a satisfactory state \\
\hline Zuzana & $\begin{array}{l}\mathrm{BQ}=3.904 \text { to think about life and work, the style and meaning- } \\
\text { fulness of life } \\
\text { (if values }=4.0 \text { to } 4.9 \text {, the presence of burnout syndrome has } \\
\text { already been demonstrated) }\end{array}$ \\
\hline
\end{tabular}


When evaluating the burnout rate, only the high school teacher Tereza was in a satisfactory state. Anna's (the primary school teacher) results were near the borderline of burnout syndrome and was advised to change her working style and overall lifestyle. The college teacher Zuzana is already having symptoms of the burnout syndrome beginning.

The following structured interviews were followed by three case studies to increase the recognition of the first signs and the understanding of the process of stress and burnout syndrome development in case of our participants. The risk of overloading and exhaustion in the teaching profession is high. Even our partial quantitative probe demonstrates that sensitivity to burnout syndrome is present in the case of all respondents. Before we compare and then describe possible preventive and therapeutic options, we need to familiarise ourselves with the following case studies.

\section{Anna}

Anna has been teaching in the area of primary education for over 36 years. She first worked at a rural primary school, and after five years she went to the city primary school where she taught until retirement. Throughout her pedagogical career, she has taught the Czech language and two other foreign languages. Although she had no ambitions to climb the career leader, she held the position of the district methodologist and the head of the subject committee, and she also led various free-time clubs. She chose her job on purpose: she wanted to work with children, to educate them, and to give them her life ideals. She did not come from a teaching family. In her work she was receptive, understanding, conscientious, and persistent. She was interested in the fate of her pupils outside the classroom as well. At the end of her career, she counted the weeks and days left until the time of her retirement because she felt very exhausted. Apart from family care (a husband and three children), she also found time for her interests (especially manual work and reading). She was an active member of the teaching staff during her career. By the school leadership, she was perceived as an extremely careful and responsible teacher. Relations with colleagues were normal. During her teaching, she was gradually feeling more mentally and physically tired and exhausted at certain periods and she was sometimes unwell. During those periods, she was losing interest in her job, which had been perceived as a mission at first. The stages of fatigue and exhaustion appeared more and more often at the end of her professional career, not only at the end of the school year. As a result of stress, physical problems were the most striking (high load - high pressure, back pain, heart pounding, neck and shoulder stiffness, intestinal troubles, excessive fatigue, insomnia, and higher susceptibility to disease). There were also emotional problems (high load - negative emotions prevailing, impatience, nervousness, anxiety, depression, restlessness, expectation of illness); the average burden was manifested in the cognitive area (difficult to concentrate on work, loss of attention, memory impairment, higher incidence of errors, and reduction of ability to correctly analyse and evaluate) and the social area (without enthusiasm for contact with others, without enthusiasm in her area of interests, an inclination to suspicion, more frequent conflicts, and problems in human relations). Although these problems were escalating, she never thought of leaving. Anna, after many years of life spent working in the staff room, gained a place in the office (which she shared with two other colleagues). This fact surely contributed to the release of psychological tension and stress. Obtaining partial privacy had a 'refreshing' effect. Anna's emotional exhaustion was high, and in the area of depersonalisation/ cynicism she reached an average number, and in the area of performance reduction there were high numbers again. The risk of burnout syndrome was average, and the BQ value was 3.4. 
She was looking forward to a well-deserved rest, and she could not imagine that she would teach in private or on a short-term basis at school. The beginning of retirement was filled with a feeling of work well done, which was also proven by a number of satisfied graduates who did not forget her and are still in contact with her.

\section{Tereza}

Tereza was an excellent student who graduated with distinction. The first disappointment caused by a conflict with reality arose at the start of her job career when she was supposed to start at a primary school. The offers to stay and work at university she did not accept because she wanted to teach at a high school. She finally joined one of the high schools, where she has spent most of her professional life (25 years). She has been teaching at a grammar school for the last five years. Her overall pedagogical practice consists of 30 years. She comes from a teacher's family; her mother has become a model for her. Tereza has wanted to be a teacher since her childhood, she chose the profession herself, and her parents agreed seeing it was suitable for her. She has never doubted her choice, for teaching was 'in her blood', even when the first disillusionment appeared. Since childhood, she has been very hardworking, keen, reliable, and self-sufficient. Her parents did not have to devote any extra care to her because she was very self-sufficient and they cared after her less independent older sibling. She tried not to worry her parents. At both schools, she would have been able to successfully ascend the career ladder thanks to her professional skills (teaching of two subjects and a foreign language) and personal qualities. But that was not the case. The headteachers of the two schools were aware of her personality and work qualities, and they began to entrust her with more and more responsible and demanding tasks. She became the coordinator of ŠVP (The School Educational Programme), carried out several EU projects, has been the responsible guarantor of cooperation with foreign countries during exchange programs, and many other activities. Tereza first understood the intense increase in work responsibilities as a compliment, but she expected a proper evaluation or promotion to come. This has not happened. Over time, she has begun to feel overwhelmed, exhausted, and irritated. She feels like a machine - in the morning she goes to work, teaches her lessons and substitution lessons, fulfils other duties of an administrative character and the duties of a class teacher, and then goes straight home where (after a very short rest or none) she prepares herself for the next day for a few hours (teaching, tests, some other administrative issues). She also spends the weekends mostly with her work duties, and she devotes little time to resting.

She takes care of the household and her husband and thus she does not have time for any hobbies (she likes reading the most). At school, she has been feeling overwhelmed by the administration, rivalry among colleagues (Tereza is working at a prestigious high school), and she has been feeling the pressure of increasing demands in the area of professional competencies. She likes and participates in the activities of DVPP (Further Education of Pedagogical Workers), and organises lectures of specialists. Thanks to her three degree studies, she has a broad professional background and she is also trying to keep in touch with the latest innovations in the field. She held the position of the new teachers' trainer, and gives lectures to her colleagues about the news in education. She likes helping and advising students and arranges many out-of-school matters for them. She is interested in her students' problems and she takes them personally. She is highly empathetic. She spends her holiday time on her personal development, she reads new materials (often beyond her own area), prepares new subjects, etc. She thinks that helping others - students and colleagues - is the key. Although she often feels physically and psychologically exhausted 
at times (mostly at the end of the semester and the school year), she is never indifferent to her surroundings. Working exhaustion in her case has repeatedly manifested itself in the form of a disease. She initially ignored it because she felt irreplaceable. After her experience of staying in hospital, she has reassessed her attitude, although sometimes she tends to go back to the old routine. The teaching profession is a mission for her, she would never teach for money alone. She only thought of leaving the teaching profession once when she changed her work place. She started (at a more advanced age) and she came into the position of a new teacher. Over time, she has shown her qualities even here, but she has felt depressed and tired. She has felt as if caught in the trap of an endless working cycle. She is rewarded by the repeated achievements of her students in competitions and their successful graduation at university. Students like to return and see her again. As a result of stress, there is a high burden in the physical area (back pain, heart palpitations, sore throat, stiff neck and shoulders, excessive fatigue, other psychosomatic problems, insomnia, and higher sensitivity to illness). In the area of emotion, her burden is average (mostly negative emotions, feelings of restlessness, nervousness, depression, annoyance, feelings of inferiority, anxiety, and fear of illness). Her results showed lower negative impact in the cognitive field (difficult concentration on work, problem solving in a random and unpredictable way, higher error rates, and a reduced ability to analyse and evaluate a situation); and in the social sphere (lack of enthusiasm in contact with others and excitement for her interests, a tendency to suspect and blame others, more frequent conflicts, and problems in human relationships). The emotional load test showed moderate emotional exhaustion, low depersonalisation/cynicism and high-performance loads. The burnout syndrome risk test showed an average risk (158 points) and BQ value was 2.2, which indicates a satisfactory state. Tereza appears to be relatively stabilised, but she must consciously take care of improving her lifestyle in order to prevent moving closer to burnout syndrome over time. She should seek to preserve (and respectively improve) her approach towards herself both at the personal and working level.

\section{Zuzana}

After graduating from college, she received a position as a lecturer at a university and she continued in her intensive studies in order to gain further academic and scientific degrees. She has been teaching for 23 years. It was her dream to become a teacher. Zuzana also comes from a teaching family, and her sister is her model. She has learned how to function without almost any rest. In the past, there were always more and more challenges ahead of her, which she fulfilled willingly and gladly. Zuzana is determined, stubborn, but also responsible and reliable. She has also experienced a gradual increase in workload at her workplace to the extent that she felt totally exhausted, mentally and physically. This was also a prestigious workplace that brought about a number of unpleasant and conflicting situations among colleagues. She has never doubted her choice of profession. Even though she had to leave her job for a short time, she returned. It took a lot of energy and work (not just physically) to get back to her dream profession. Zuzana tends towards workaholism and perfectionism, which has brought her (over the years) into a situation where her body finally went on strike and she almost collapsed. Then she realised that she had reached breaking point and it would be necessary to start to rest, and not to work all weekends and holidays regularly. She has not had holidays without work for almost two decades. She tries to rest briefly every day after work (so she can provide energy for herself for a short time) but the demands of the profession make her exhausted at the end of each semester. The state of total exhaustion has gradually almost disappeared, but sometimes it suddenly returns. Health problems are also co- 
ming back, but (so far) they do not bring a higher illness rate. Zuzana is single and childless; she cares about her older parents. She is also in charge of a large garden and a house, so she goes 'from work to work'. Her hobbies include gardening, walking the dog, reading, painting, and handcrafts. Zuzana does not correctly evaluate her excessive workload; she often does not fully perceive it. Due to the collapse she realised that there needs to be a change in her attitude towards herself and her profession. She is often successful, but occasionally she returns to the old routine. If she is severely exhausted, she has problems with communication and carrying out her work responsibilities, and she shows symptoms of procrastination. She is fully aware of the situation and she is trying to resolve it. She hopes that her condition will improve over time and she will not end up with fully developed burnout syndrome. In the stress susceptibility questionnaire, Zuzana has a high cognitive, emotional, and physical load. Her personality level score is at average numbers. In the cognitive area, she has problems with concentrating on work, loss of attention, memory decrease, problem solving in a random and unpredictable way, a higher incidence of mistakes during problem solving issues than usual, and a decreased ability to properly analyse and evaluate situations. In the emotional area, negative emotions predominate - impatience, restlessness, nervousness, depression, fear, inferiority complex, anxiety, problems with mental and physical rest, the expectation of illness, and the fear of illness. The physical area problems involve high blood pressure, back pain, heart palpitations, dry throat, sweaty hands, excessive fatigue or even fatigue syndrome, insomnia, etc. In the social area, stress overload sometimes manifests itself by a deterioration in coherent speaking, a lack of enthusiasm for contact with others and for the realisation of interests, a tendency to suspect and blame others, and an awareness of more frequent conflicts and problems in relationships with people. Emotional exhaustion shows a high number (3.20), depersonalisation/cynicism is at a low level, and there is an average number for her performance efficiency. The danger of burnout syndrome has been tested and shows an average number (154 points). Such a result indicates that there is still the opportunity to resolve the problems. BQ value is 3.904 (the presence of burnout syndrome is shown when the value equals 4.00). Zuzana should think about her life, lifestyle, work, and meaningfulness of life.

\section{Comparison}

It has been proven that none of the teachers are yet in the stage of fully developed burnout syndrome although they have been driven towards it. The investigation has shown that the burnout process is long-term, creeping, and is a process developing in stages that contains symptoms of physical, emotional, and mental types, and behavioural changes. In all three cases included in our survey, the average risk of burnout syndrome (one participant was near the threshold for its full development) was proven. In our sample (where we also targeted an individual from the university environment), all three factors of the syndrome are gradually emerging: all teachers have encountered a high degree of emotional exhaustion, partly with depersonalisation, and with a partial reduction in work efficiency. It is not yet a state of total exhaustion, i.e., developed burnout syndrome. However, it is clear that their burnout process needs to be slowed down and stopped. The teaching profession is 'dangerous', above all due to overloading from stress and emotional exhaustion. These are reflected in the teacher's psychological state, in his or her health, and behaviour.

All of the participants in the research study understand their profession (even the former teacher) as a mission and they would never want to exchange it for another one (Zuzana returned back to her dream career). Their personality is more introverted, and they are connected by their effort to work as accurately as possible, by their sense of responsibility, even perfectionism. This is parti- 
cularly evident in the case of the daughters. They all have a strong internal drive mechanism and the will in their job to achieve excellent results with their assigned students. All of the participants are professionally fully-adapted (Anna is already retired) and have mature personalities. Stress and exhaustion are manifested by lower self-confidence, unstable emotional balance, and poorly perceived work/life satisfaction. They often feel socially isolated. In the case of both daughters (at the time of their beginnings at work), their internal ideals were confronted with reality. This state was soon overcome. Now, from the position of teacher-experts with sufficient experience, they tend to overestimate their strength and, due to psychological and physical fatigue, they are in danger of burnout syndrome. Sources from abroad refer to the symptoms of exhaustion, fatigue, and apathy in the case of older teachers with many years of experience, which was confirmed in our survey. However, Kebza and Šolcová disprove this concept. ${ }^{40}$ They claim that burnout syndrome is not related to gender or length of practice. Our research probe does not agree with their opinion, as well as a number of previous final theses. For example, Nesvadbová, ${ }^{41}$ who examined the extent of sensitivity to burnout syndrome among primary school teachers and nursery school teachers, showed a higher level of psychosocial burden and burnout syndrome levels among primary school teachers, particularly at the emotional and physical levels. Our research has also confirmed this. The author also concluded that for a group of teachers with experience between 21-30 years, sensitivity to the syndrome is higher than for pedagogues with a lower or higher number of years of practice. ${ }^{42}$ This hypothesis has not been confirmed in our research.

External factors contribute to the setup of individual stages of exhaustion and burnout syndrome. First of all, we mention the family - our research sample has encountered a high level of commitment to family and personal relationships (care for family members, excessive care for the household, including gardening, etc.), where there is not much time to relax and spend some free time. Some final theses have shown (for example, Stiburrková, 2007) that the feeling of being overloaded and overworked is felt by women rather than men. Also, the work environment and the school atmosphere bring a number of stressors - our participants complained about the increasing administrative burden of the profession (constant legislative changes and reforms of Czech education), increasing demands on teachers and their responsibility for pupils' education and training, the emotional and time demand of the job, rivalry, overload, fears of falling demographic trends, feminisation of education, but also a lack of mutual cooperation and motivation, a lack of education on the subject, and zero supervision, etc. They also mentioned the underestimated status of the teacher's profession and the fact that the young generation of teachers is not in schools, etc. Stiburrkova, in her final thesis ${ }^{43}$, examines the rate of burnout syndrome in seven school facilities (early-child care institution, kindergarten, primary school, secondary vocational school, grammar school, college, and a pedagogical-psychological counselling facility). She points out that the higher the level of educational institution, the higher the risk of burnout syndrome. Our research probe did not confirm this: on the one hand, the university teacher (our participant) has the symptoms of the burnout syndrome; on the other hand, a high level of the threat is present in the case of our primary school teacher, too. Furthermore, Stibůrková ${ }^{4}$ proved that the higher the education of pedagogical workers, the lower the symptoms of burnout syndrome. This point, in

40 Cf. Vladimír KEBZA - Iva ŠOLCOVÁ, Syndrom vyhoření, Praha: Geoprint, 2003.

41 Cf. Ilona NESVADBOVÁ, Syndrom vyhoření učitele, Univerzita Palackého v Olomouci, Filozofická fakulta, Katedra sociologie a andragogiky, 2013.

42 Ibid. pp 49-50.

43 Cf. Lenka STIBU゚RKOVÁ, Syndrom vyhoření v učitelské profesi (diploma theses), Brno: PF MU, 2007.

44 Cf. Ibid. 
terms of our research, is worth our attention - we found out that none of the research participants was trained in the issue of burnout syndrome during their undergraduate education; the same situation also occurs in the context of the further education of teaching staff at present time.

As has been proven, it is a great advantage for all of the research participants that they can share their experiences and problems with each other in the family circle and that they can help or give advice to each other. However, in terms of burnout prevention, we did not see any significant preventive impact; the mother has been repeatedly pointing out to her daughters that they cannot only work and that they also must pay close attention to relaxing in their free time. Her daughters agree, but (under the influence of everyday working reality and their character dispositions) their working regime is not changing much.

\section{Prevention and Intervention Techniques}

While burnout syndrome belongs to areas of interest primarily for basic research, this is not the case with therapeutic procedures. These should systematically become the goal of applied research. Preventive and intervention strategies for burnout syndrome can be divided into two basic groups $^{45}$ - the first belongs to the level of primary prevention which deals with selected aspects of prevention; and the second belongs to the level which involves intervention techniques. These techniques can be divided into individual, social, and organisational strategies. Individual strategies try to reduce the presence of stress, which is caused by a number of factors. Most often it concerns the organisation and better structure of non-working time (including the development of good physical condition (mental hygiene, diet, exercise), social support (relationships), a positive view of life, a knowledge of one's own abilities, the strengthening of self-confidence, etc.). In the educational environment, cognitive-control and psychodynamic methods (for example, a course of assertiveness, social skills training, problem solving techniques, hidden modelling, self-control techniques, cognition techniques, the stopping of negative thinking, etc.) and methods of physical exercise (relaxation techniques, breathing exercises, meditation techniques, etc.) are used. Group techniques basically correspond to previous techniques with one exception - they are applied to a larger number of participants in seminar form. Relaxation techniques, problem solving, debates on important issues, etc., are suitable. Organisational strategies are closely related to the further education of pedagogical staff. The best successes in the fight against stress and burnout syndrome can be expected when combining single strategies, i.e., individual, group, and organisational. Teachers should know their own adaptation mechanisms, the effects of stress on the human organism, the causes of burnout syndrome, and the methods of prevention and intervention. This will enable them to actively approach occupational and personal stressful situations, to use the possibilities (in order to reduce stress), and to use the potential for personality development that will be professionally adaptable, satisfied, and able to cope with stress and burnout syndrome. Křivohlavý and Pečenková consider the best prevention 'to live a meaningful life' in which stressors are balanced. ${ }^{46}$ Maroon puts emphasis on an awareness of the problem, actively taking responsibility, clear thinking and development of understanding, and gaining new knowledge to manage and improve strategies. ${ }^{47}$ Matoušek emphasises the clear mission of the organisation,

45 Cf. Eloísa GUERRERO BARONA - Jesús Carlos RUBIO JIMÉNEZ, Estrategias de prevención e intervención del Burnout en el ámbito educativo. Salud Mental, vol. 28, no. 5, octubre 2005, p. 29. 
exact methods, and the elimination of administrative burden. ${ }^{48}$ Klenarová and Matějková refer to personal prevention combined with workplace prevention based on good relationships at the workplace, job evaluation, control system, supervision, etc. ${ }^{49}$ Lhotková, Šnýdrová and Tureckiová emphasise two strategies - a strategy for solving the problem and a strategy for dealing with the emotional state. ${ }^{50}$ Vávrová highlights a well-functioning system of continuing education of workers (especially in the area of soft skills), and the offering of individual and group supervision..$^{51}$ As an effective prevention of burnout syndrome can be considered lifelong learning, which will focus (for example) on the ability to effectively plan time or to manage mental and physical stress at work and in personal life. Overcoming burnout syndrome is difficult. It is much easier to prevent it. If there is a situation where a teacher needs help from a specialist, existential psychotherapy, daseinsanalysis, and logotherapy are recommended. ${ }^{52}$

\section{Conclusion}

The world in which we live is overwhelmed by information and, at the same time, humanely malnourished from the human point of view. The role of workers in helping professions is becoming increasingly important. The previously neglected spiritual dimension of life and human service emerges. The teacher is the one who leads and accompanies, shows the way as well as the boundaries, and explains the crossroads. ${ }^{53} \mathrm{He}$ or she helps to unlock pupils' potential. He or she is the representative of the pupil's hope for education and a fulfilled life. The teacher should interpret the world using his or her mind and heart, allowing pupils to become mature, free, and responsible. The focus is on shaping the integrity of the physical-psychological-social-spiritual unity of human existence. The highest triad of values of Truth, Goodness and Beauty remains an eternal challenge. According to Z. Neubauer, education is the ability to see the experience in a light that I have not only accepted from the outside, but which I have created from the best that is in me. This is the sovereign task for the teacher - igniting the fire in the student's soul. Fire cannot be ignited by one who is burned out. That way the blind man does not lead another blind one.

Burnout syndrome deserves increased attention not only in the teaching profession. Every year, new graduates of the helping professions begin their career. It is necessary to intervene in time in order to minimise the experience of burnout syndrome. Finally, allow me to lighten the mood a little - according to NASA, the teaching profession needs similar features that are necessary for top pilots: 'Teaching at school is as demanding as driving a shuttle, if not more demanding and more dangerous. ${ }^{54}$ The development of burnout syndrome depends not only on the personality of the teacher, the working environment, interpersonal relationships, the attitude of superiors, and the promotion of professional development, but also on the family environment, the lifestyle, and the overall prestige of the teaching profession. Targeted prevention and intervention strategies in the educational area should reduce the incidence of burnout syndrome among teachers, who represent one of the most widespread and oldest professions in human history. Let us hope that in

48 Cf. Oldřich MATOUŠEK, Metody a řizení sociální práce, Praha: Portál, 2008, p. 58.

49 Cf. Jarmila KELNAROVÁ - Eva MATĚJKOVÁ, Psychologie 2. díl: pro studenty zdravotnických oborů, Praha: Grada, 2014, p. 67.

50 Cf. Irena LHOTKOVÁ - Ivana ŠNÝDROVÁ - Michaela TURECKIOVÁ, Sebeřízení vedoucího pracovníka ve školství, Praha: Wolters Kluwer, 2013, p. 85.

51 Cf. Soňa VÁVROVÁ, Doprovázení s pomáhajících profesích, Praha: Portál, 2012, p. 126.

52 Cf. Eloísa GUERRERO BARONA - Jesús Carlos RUBIO JIMÉNEZ, Estrategias de prevención e intervención del Burnout en el ámbito educativo, p. 31.

53 Cf. HELUS - BRAVENÁ - FRANCLOVÁ, Perspektivy učitelství, p. 86.

54 Václav HOLEČEK, Psychologie..., back page of the book. 
the future we will meet Bartleby the Scrivener among our colleagues only exceptionally.

\section{A Professional Teacher as 'Bartleby the Scrivener'? Rather not! Occupational Burnout in the Teaching Profession}

\section{Abstract}

The text deals with the teaching profession in the 21 st century as a convergence of its several forms (occupation, job, mission, and profession) and a teacher as a worker, craftsman or artist, and at the same time as a reflecting professional, researcher and expert. Furthermore, it focuses on the multifactorial phenomenon of occupational burnout as a significant psychosomatic disorder among teachers.

Keywords: teaching profession, forms of teaching, occupational burnout

\section{Author contact}

Assoc. Prof. Dr. Helena Zbudilová

University of South Bohemia in České Budějovice

Faculty of Theology, Department of Pedagogy

Kněžská 8, 37001 České Budějovice

Email: hzbudilova@tf.jcu.cz 